\title{
De Martonne-Gottman ve Standart Yağış İndeksi yöntemleri kullanılarak kuraklığın belirlenmesi: Isparta ili örneği
}

\author{
İbrahim Dursun ${ }^{\mathrm{a}}$ (D), Ahmet Alper Babalıka,* (D)
}

\begin{abstract}
Özet: Kuraklık, belirli bir zaman diliminde topraktaki nem yetersizliğini, yetersiz yağış veya yağışsız periyotları ifade eden bir kavramdır. Kuraklığın zamansal ve alansal özelliklerini belirlemek için farklı kuraklık indisleri kullanılmaktadır. Bu çalışmanın amacı kuraklık indislerinden De Martonne-Gottman ve Standart Yağış İndeksi (SYİ) yöntemlerini kullanarak Isparta ilinde kuraklığı belirlemektir. Bunun için Atabey, Eğirdir, Isparta (Merkez), Senirkent, Uluborlu ve Yalvaç Devlet Meteoroloji İstasyonlarından alınan 31 yıllık (1990-2020) yağış ve sıcaklık verileri kullanılmıştır. De Martonne-Gottman yöntemine göre yapılan değerlendirmeler sonucunda Atabey, Eğirdir, Isparta (Merkez), Uluborlu ve Yalvaç ilçelerinin "Step (Yarı Kurak)-Nemli" arası iklim tipinde olduğu tespit edilirken, Senirkent ilçesinin "Yarı Nemli" iklim tipinde olduğu belirlenmiştir. Bununla birlikte çalışma alanının SYI'ye göre aylık yağıș verileri kullanılarak 1, 3, 6,9 ve 12 aylık SYİ değerleri ile alandaki kurak ve yağışlı dönemlerin şiddeti, büyüklüğü ve dağılımı tespit edilmiştir. Araştırma alanının genelinde normale yakın kuraklık dönemleriyle karşılaşılmıştır. SYİ 12 aylık değerleri göz önüne alındığında kuraklığın en uzun sürdüğ̈ dönem Yalvaç ilçesinde 67 ay (Eylül 2004 - Mart 2010) olarak belirlenmiştir. 12 aylık SYİ değerleri için kuraklık oluşum yüzdeleri incelendiğinde en fazla oranın \%52.3 ile Isparta (Merkez)'da olduğu tespit edilmiştir.

Anahtar kelimeler: Kuraklık, De Martonne-Gottman, Standart yağı̧̧ indeksi, Isparta
\end{abstract}

\section{Determination of drought using De Martonne-Gottman and Standardized Precipitation Index methods: A case study in Isparta province}

\begin{abstract}
Drought is a concept that expresses the lack of moisture in the soil, precipitation deficiency or periods of no precipitation in a certain period. Different drought indices have been used to determine the temporal and spatial characteristics of drought. The aim of this study is to determine the drought in Isparta province by using De Martonne-Gottman and Standardized Precipitation Index (SPI) methods from drought indices. For this, 31-year (1990-2020) precipitation and temperature data from Atabey, Eğirdir, Isparta (Center), Senirkent, Uluborlu and Yalvaç State Meteorology Stations were used. As a result of the evaluations were made according to the De Martonne-Gottman method, it was determined that Senirkent district has "Semi-Humid" climate type while it was determined that the areas belonging to the districts such as Atabey, Eğirdir, Isparta (Center), Uluborlu and Yalvaç have the "Step (Semi-Arid)- Humid" climate type. In addition, the severity, size and distribution of the dry and rainy periods in the area and 1, 3, 6, 9 and 12-month SPI values were determined by using monthly precipitation data according to the SPI of the study area. Near-normal drought periods were encountered throughout the study area. Considering the 12-month SPI values, the period that the drought lasts the longest has been determined as 67 months (September 2004 - March 2010) in Yalvaç district. When the drought occurrence percentages for the 12-month SPI values are examined, it was determined that the highest percentage was Isparta (Center) with $52.3 \%$.
\end{abstract}

Keywords: Drought, De Martonne-Gottman, Standardized precipitation index, Isparta

\section{Giriş}

Su, doğada canlıların varlıklarını sürdürebilmeleri ve yaşam alanları oluşturabilmeleri açısından vazgeçilmez bir doğal kaynaktır (Akın ve Akın, 2007). Aynı zamanda su, tarım-ormancıllk ve hayvancılık üretimine doğrudan etkili olduğu için, özellikle tarım ekosistemlerinde insan yaşamını sürdürmenin kilit kaynaklarından biridir (Valipour, 2015). Ekosistemlerin devamlılığı açısından suya olan ihtiyaç oldukça önemlidir (Bhangale vd., 2020). Dünyada 43 ülkede yaklaşı 700 milyon insanın su kıtlığından etkilendiği tahmin edilmekte olup, 2025 yılına kadar 1.8 milyar insanın mutlak su kıtlığı olan ülkelerde veya bölgelerde yaşayacağı ve dünya nüfusunun üçte ikisinin su sıkıntısı koşullarında yaşayabileceği uzmanlar tarafından tahmin edilmektedir (Zarei ve Eslamian, 2017; Yokomatsu vd., 2020).

Dünyada kişi başına kullanılabilir su miktarı yıllık olarak kategorize edilmiştir. Bu miktar $1000 \mathrm{~m}^{3}$ 'ten az ise su fakiri, $1000-2000 \mathrm{~m}^{3}$ arasında ise su kitlı̆g bulunan, $2000 \mathrm{~m}^{3}$ 'ten fazla ise su zengini ülkeler şeklinde nitelendirilmektedir (Acar, 2018; Turan ve Bayrakdar, 2020). Bu bağlamda ülkemizde, yılda kişi başına düşen kullanılabilir su miktarı $1.400 \mathrm{~m}^{3}$ olup, Türkiye su zengini bir ülke değil, su stresi $\llbracket$ a Isparta Uygulamalı Bilimler Üniversitesi Orman Fakültesi Orman Mühendisliği Bölümü, Isparta

@ * Corresponding author (İletişim yazarı): alperbabalik@ isparta.edu.tr

$\checkmark \quad$ Received (Geliş tarihi): 28.05.2021, Accepted (Kabul tarihi): 12.07 .2021
Citation (Atıf): Dursun, İ., Babalık, A.A., 2021. De Martonne-Gottman ve Standart Yağıș İndeksi yöntemleri kullanılarak kuraklığın belirlenmesi: Isparta ili örneği. Turkish Journal of Forestry, 22(3): 192-201.

DOI: $10.18182 / \mathrm{tjf} .944195$ 
altında bir ülke durumundadır (Karataş ve Çevik, 2010; Kurtoğlu, 2018).

Yarı kurak/yarı nemli iklim kuşağında yer alan ülkemizde atmosferik koşullar ve iklim koşullarının etkisiyle dönemsel olarak bazı dönemlerde daha kurak iklim tipleri görülürken bazı dönemlerde ise daha nemli iklim tipleri görülmektedir (Şahin ve Kurnaz, 2014). Kuraklık, mevcut su kaynakları ve yağış miktarındaki değişimden kaynaklanmaktadır. Kuraklık olgusu tüm bölgelerde değişen sıklık ve yoğunlukta ortaya çıkabilmektedir (Pathak ve Dodamani, 2016).

Genel olarak kuraklık, meteorolojik kuraklık, tarımsal kuraklık, hidrolojik kuraklık ve sosyo-ekonomik kuraklık olmak üzere 4 kategoriye ayrilmaktadır (Wilhite ve Glantz, 1985; Mishra ve Singh, 2010). Tüm kuraklıklar ilk olarak meteorolojik, yani yağışın yeteri kadar olmamasıyla başlamaktadır. Sonrasında bu durumu toprak neminin azalması ve bitkilerin ihtiyaç duydukları minimum su kapasitelerinin azalmasıyla tarımsal kuraklık takip etmektedir. Daha sonraki süreçte akarsu ve barajlardaki su kapasitelerinin azalmasıyla hidrolojik kuraklık olgusu görülmekte ve tüm bu durumların etkisi sonucunda kuraklık kendini sosyo-ekonomik kuraklık olarak göstermektedir (Akbaş, 2014). Kuraklığın tarımsal üretimde ve sosyoekonomik durumlar gibi bir ülkenin dinamikleri üzerindeki olumsuz etkileri olması sebebiyle, kuraklığı tespit edebilmek için bilim adamları tarafindan günümüzde çok çeşitli kuraklık indeksleri geliştirilmiştir. Kuraklık indeksleri, kuraklığın belirlenmesinin ve izlenmesinin en etkili yolu olarak görülmektedir. Böylece kuraklığın sayısal olarak süresinin ve şiddetinin belirlenmesi mümkün olabilmektedir. Kuraklık belirleme yöntemlerinin temelinde belirli bir alanda kuraklığ tam olarak belirlemek ve hangi zaman koşulunda ve nerede oluşacağı belli olmayan kuraklık kavramını ortaya koymak yer almaktadır (Topçu ve Karaçor, 2021; McKee vd., 1993).

Bu çalışmada De Martonne-Gottman ve SYİ yöntemleri kullanılarak Isparta ilinin kuraklık durumu belirlenmeye çalışılmıştır. Böylelikle Türkiye'nin göller bölgesi olarak adlandırılan bu coğrafyada meydana gelen iklim değişimi ile kuraklık durumunun gelecekte nasıl olacağına yönelik çalışmaların yapılmasına ve gerekli önlemlerin alınmasına da olanak sağlanacaktır.

\section{Materyal ve yöntem}

Çalışma alanı olan Isparta ili, Akdeniz Bölgesinde, Toros dağlarının kuzeyinde göller yöresi olarak adlandırılan lokasyonda yer almaktadır. Isparta'nın yüzölçümü 8933 $\mathrm{km}^{2}$ 'dir. İlin doğusunda Konya ili, batısında Afyon ve Burdur illeri, kuzeyinde yine Afyon ili, güneyinde ise Antalya ili bulunmaktadır (IÇŞİM, 2019). Isparta ili, Akdeniz iklimi ile Orta Anadolu'da hüküm süren karasal iklim arasında geçiş bölgesinde yer almaktadır (Babalık, 2014). Bu nedenle il sınırları içerisinde her iki iklimin de özellikleri kendini göstermektedir. Uzun yıllar ortalamalarına göre Isparta'da yıllık ortalama sıcaklık $12.6{ }^{\circ} \mathrm{C}$, yıllık toplam yağış miktarı ise $519.5 \mathrm{~mm}$ 'dir. Çalışmada, gerekli meteorolojik verilerin temin edilebildiği Atabey, Eğirdir, Isparta (Merkez), Senirkent, Uluborlu ve Yalvaç ilçelerinde (Şekil 1) bulunan meteoroloji istasyonlarına ait 31 yıllık (1990-2020) yağış ve sıcaklık değerleri kullanılmıştır (DMİ, 2021).

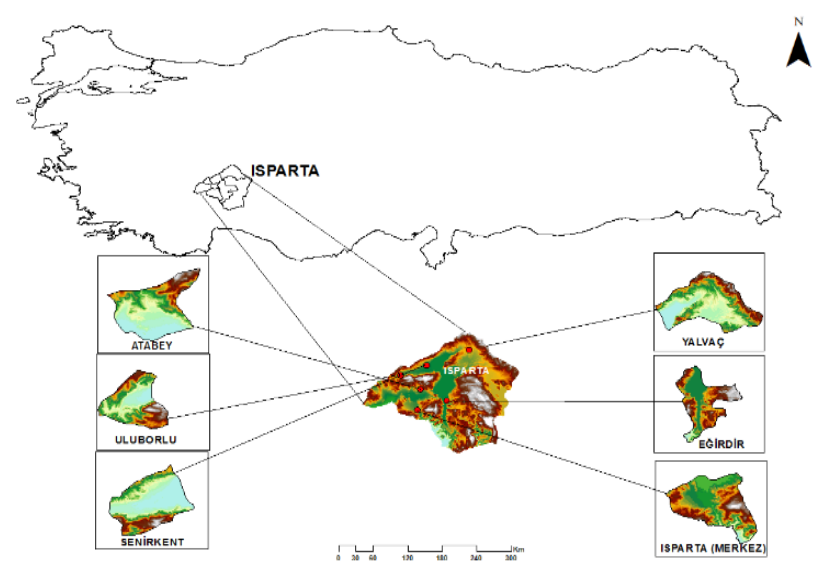

Şekil 1. Isparta ilinin ve istasyonların konumu

Çalışmada, Isparta ilinin kuraklık durumunu ortaya koymak için De Martonne-Gottman İndisi ve SYİ iklim sınıflandırması ile kuraklık analizi yapılmıştır.

\subsection{De Martonne - Gottman Indisi}

De Martonne indisi y1llık ortalama sicaklık ve yıllık toplam yağış verileri baz alınarak hesaplanmaktadır. Hesaplama sonucunda "Yıllık Kuraklık İndisi" değerleri elde edilmektedir (De Martonne, 1926). De Martonne indisinin, Gottman ile birlikte formülde ilk haline bazı eklemeler ve düzeltmeler yapılması ile De Martonne - Gottman indisi elde edilmiştir (MGM, 2016). Buna göre; De Martonne (1942) tarafindan oluşturulan eşitlik (1) formülüne göre indeks değeri elde edilmektedir.

$\mathrm{I}_{\mathrm{DMG}}=\frac{1}{2} *\left(\frac{\mathrm{P}}{\mathrm{T}+10}+\frac{12 * \mathrm{Pd}}{\mathrm{Td}+10}\right)$

Burada $\mathrm{I}_{\mathrm{DMG}}$; De Martonne-Gottman indisi değeri, P; yıllık toplam yağış $(\mathrm{mm}), \mathrm{T}$; yıllık ortalama sıcaklık $\left({ }^{\circ} \mathrm{C}\right), \mathrm{Pd}$; en kurak ayın yağışı $(\mathrm{mm}), \mathrm{Td}$; en kurak ayın ortalama sıcaklığ $1\left({ }^{\circ} \mathrm{C}\right)$ 'dır. Bu denkleme göre yıllık ortalama sıcaklık ve yıllık yağış toplamı değerlerinin dışında en kurak ayın sıcaklık ve yağış değerleri kullanılmıştır. Sınıflandırma Çizelge 1'e göre yapılmaktadır.

\subsection{Standart Yağış İndeksi (SYİ)}

SYİ yöntemi ilk olarak Mckee vd. (1993) tarafından ortaya konulmuştur. SYİ, belirlenen zaman periyodunda yağışın ortalamadan olan farkının standart sapmaya bölünmesi ile eşitlik (2)'ye göre hesaplanmaktadır. İki parametrenin yeterli olduğu basit pratik bir yöntemdir. SYİ yağışların analizinde kuraklık değişkenliğinin bir göstergesi olup, 1, 3, 6, 9, 12'şer aylık periyotlarda değerlendirilmektedir (Zhang vd., 2017). Bu yöntemde en az 30 yıllık yağış kayıtları kullanılmaktadır.

Çizelge 1. De Martonne indeks değerleri ve iklim özelliği

\begin{tabular}{cc}
\hline Kuraklık indeksi & İklim özelliği \\
\hline $0-5$ & Çöl \\
$5-10$ & Step (Yarı kurak) \\
$10-20$ & Step-Nemli arası \\
$20-28$ & Yarı nemli \\
$28-35$ & Nemli \\
$35-55$ & Çok nemli \\
$>55$ & Islak \\
$<0\left(\mathrm{~T}<-5^{\circ} \mathrm{C}\right)$ & Kutupsal \\
\hline
\end{tabular}


$S Y \dot{I}=\frac{X_{\dot{I}}-X_{\text {ort }}}{\sigma}$

Burada SYİ; Standart Yağış İndeksi, Xi; aylık yağış miktarı, Xort; uzun süreli aylık yağışların ortalaması, $\sigma$ ise yağış miktarlarının standart sapmasıdır. SYİ, gama fonksiyonu kullanarak uzun vadeli yağışların olasılık dağılımına dayalı olarak kuraklık koşullarını değerlendirmek için tasarlanmıştır. Gama fonksiyonuna bakacak olursak genelde yağış serileri normal dağılıma uymamaktadır. Bunun için SYİ değerlerinin normal dağılıma dönüştürülmesi gerekmektedir. $\mathrm{Bu}$ amaçla yağış verilerine en iyi uyan olasılık dağılımı Gamma olasılık dağılımı olduğundan SYİ yönteminde, yağış verilerinden elde edilen olasılık dağılımı Gamma olasılık dağılımına dönüştürülmektedir (Thom, 1966; McKee vd., 1993; McKee vd., 1995).

Gamma fonksiyonu eşitlik (3) ile hesaplanmaktadır.

$g(x)=\frac{1}{\beta^{\alpha} \Gamma(\alpha)} x^{\alpha-1} e^{\frac{x}{\beta}} x>0$

Burada $\alpha>0$ şekil parametresini, $\beta>0$ ölçek parametresini, $\Gamma(\alpha)$ Gama fonksiyonunu, $x$ : yağış miktarını $(x>0)$ ifade etmektedir.

Yine $\alpha$ ve $\beta$ 'nın tahmininde eşitlik (4), (5), (6) nolu olasılık çözümleri kullanılmaktadır.

$\alpha=\frac{1}{4 A}+\left(1+\sqrt{1+\frac{4 A}{3}}\right)$

$\beta=\frac{\bar{x}}{\alpha}$

$A=\ln (\bar{x})-\frac{\sum \ln (x)}{n}$

Burada, n: yağış gözlemlerinin sayısıdır. Gözlenmiş zaman serileri kullanılarak elde edilen bu parametreler daha sonra herhangi bir ayda gözlenmiş bir değerin toplam olasılık yoğunluk fonksiyonunu bulmak için kullanılır. Bu durumda toplam olasılık dağılım fonksiyonu eşitlik (7)'ye göre yapılmaktadır.

$g(x)=\int_{0}^{\mathrm{x}} g(x) d x \frac{1}{\beta^{\alpha} \Gamma(\alpha)_{0}} \int_{0}^{\mathrm{x}} x^{\alpha-1} \quad e^{-x /} \beta_{d x}$

Gama fonksiyonu $\mathrm{x}=0$ için tanımsızdır ve yağış dağılımı sıfır (0) değerler içerebilir; bu durumda toplam olasılık dağılımı eşitlik (8)'e göre yapılmaktadır.
$H(x)=q+(1-q) G(x)$

Bu eşitlikte q sıfır değeri için olasılığı ifade eder. Ĕ̆er m bir yağış serisinde yağışsız günlerin sayısı ise bu yüzde eşitlik (9) ile bulunmaktadır.

$$
q=\frac{m}{n}
$$

Toplam olasılık değeri H(x), ortalaması sıfır (0) ve bir (1) varyans değeri taşıyan, SYİ değerini ifade eden standart normal rastgele değerli $\mathrm{Z}$ değişkenine dönüştürülür. $\mathrm{H}(\mathrm{x})$, SYI'nin değeridir (Panofsky ve Brier, 1958; Özfidaner ve Topaloğlu, 2020). SYİ yönteminde Çizelge 2'ye göre sinıflandirma yapılmaktadır.

\section{Bulgular ve tartışma}

\subsection{De Martonne - Gottman Indisi}

Isparta ili için yapılan De Martonne-Gottman kuraklık analizinde yıllık toplam yağış ve yıllık ortalama sıcaklık verileri ile en kurak aya ait yağış ve sıcaklık değerleri kullanılmıştır. Yapılan analiz sonucunda kuraklık indeks değerlerinin zamana bağlı olarak değişimi Atabey, Eğirdir, Isparta (Merkez), Senirkent, Uluborlu, Yalvaç ilçeleri için grafik ve çizelgeler halinde aşağıda verilmiştir.

Elde edilen indis değerlerine (Ia) göre Atabey, Eğirdir ve Isparta (Merkez) istasyonları için 1990-2020 y1lları aralığında yapılan sınıflandırma Çizelge 3'de, bu indis değerlerine karşılık gelen iklim sınıflandırma grafikleri ise Şekil 2'de verilmiştir.

Çizelge 2. SYİ yöntemine göre kuraklık sınıfları

\begin{tabular}{cc}
\hline SYİ değerleri & Kuraklı sinıfi \\
\hline 2.00 veya daha fazla & Ekstrem nemli \\
$1.50-1.99$ & Şiddetli nemli \\
$1.00-1.49$ & Orta nemli \\
$0.0-0.99$ & Hafif nemli \\
$0.0-(-0.99)$ & Hafif kurak \\
$(-1.00)-(-1.49)$ & Orta kurak \\
$(-1.50)-(-1.99)$ & Şiddetli kurak \\
$(-2.00)$ veya daha az & Ekstrem kurak \\
\hline
\end{tabular}

Çizelge 3. De Martonne yöntemine göre Atabey, Eğirdir ve Isparta'nın kuraklık indis değerleri

\begin{tabular}{|c|c|c|c|c|c|c|c|c|c|c|c|c|c|}
\hline & \multicolumn{2}{|c|}{ Atabey } & \multicolumn{2}{|c|}{ Eğirdir } & \multicolumn{2}{|c|}{ Isparta } & & \multicolumn{2}{|c|}{ Atabey } & \multicolumn{2}{|c|}{ Eğirdir } & \multicolumn{2}{|c|}{ Isparta } \\
\hline Y1l & $\mathrm{Ia}$ & Sinıf & Ia & Sinıf & $\mathrm{Ia}$ & Sinıf & Y1l & Ia & Sinıf & Ia & Sinıf & Ia & Sinıf \\
\hline 1990 & 7.53 & YK & 12.73 & YK-NA & 9.22 & YK & 2005 & 10.77 & YK-NA & 20.20 & YN & 16.43 & YK-NA \\
\hline 1991 & 12.01 & YK-NA & 20.01 & YN & 15.92 & YK-NA & 2006 & 8.28 & YK & 23.94 & YN & 17.18 & YK-NA \\
\hline 1992 & 10.61 & YK-NA & 15.94 & YK-NA & 11.78 & YK-NA & 2007 & 5.26 & YK & 18.27 & YK-NA & 12.03 & YK-NA \\
\hline 1993 & 7.24 & YK & 15.77 & YK-NA & 8.51 & YK & 2008 & 6.43 & YK & 10.54 & YK-NA & 12.78 & YK-NA \\
\hline 1994 & 9.11 & YK & 18.33 & YK-NA & 18.00 & YK-NA & 2009 & 25.28 & YN & 25.82 & YN & 18.02 & YK-NA \\
\hline 1995 & 10.05 & YK-NA & 20.25 & YN & 12.30 & YK-NA & 2010 & 14.92 & YK-NA & 18.74 & YK-NA & 13.43 & YK-NA \\
\hline 1996 & 14.90 & YK-NA & 25.28 & YN & 15.39 & YK-NA & 2011 & 7.25 & YK & 15.31 & YK-NA & 9.81 & YK \\
\hline 1997 & 11.88 & YK-NA & 19.72 & YK-NA & 15.64 & YK-NA & 2012 & 11.17 & YK-NA & 18.56 & YK-NA & 13.56 & YK-NA \\
\hline 1998 & 11.27 & YK-NA & 20.01 & YN & 15.02 & YK-NA & 2013 & 10.97 & YK-NA & 16.01 & YK-NA & 16.69 & YK-NA \\
\hline 1999 & 10.31 & YK-NA & 15.80 & YK-NA & 7.07 & YK & 2014 & 13.95 & YK-NA & 22.21 & YN & 16.31 & YK-NA \\
\hline 2000 & 11.70 & YK-NA & 15.34 & YK-NA & 10.52 & YK-NA & 2015 & 13.81 & YK-NA & 21.36 & YN & 13.29 & YK-NA \\
\hline 2001 & 12.29 & YK-NA & 22.35 & YN & 14.52 & YK-NA & 2016 & 18.38 & YK-NA & 18.65 & YK-NA & 15.62 & YK-NA \\
\hline 2002 & 13.08 & YK-NA & 21.28 & YN & 13.23 & YK-NA & 2017 & 13.09 & YK-NA & 19.27 & YK-NA & 12.75 & YK-NA \\
\hline 2003 & 12.50 & YK-NA & 21.0 & YN & 15.33 & YK-NA & 2018 & 16.52 & YK-NA & 19.08 & YK-NA & 10.75 & YK-NA \\
\hline 2004 & 8.75 & YK & 18.27 & YK-NA & 13.09 & YK-NA & 2019 & 11.15 & YK-NA & 21.61 & YN & 9.25 & YK \\
\hline & & & & & & & 2020 & 9.06 & YK & 16.31 & YK-NA & 9.49 & YK \\
\hline
\end{tabular}


Atabey ilçesi için Çizelge 3 incelendiğinde, "yarı kurak", "yarı kurak-nemli arası" ve "yarı nemli" iklim sınıfları tespit edilmiştir. Yarı kurak iklim sınıfının 1990, 1993, 1994, 2004, 2006-2008 arası, 2011 ve 2020 yıllarında hakim olduğu belirlenmiştir. Yarı nemli iklim sınıfının sadece 2009 yılında hakim olduğu saptanmıştır. İlçede 1991, 1992, 1995-2003 aras1, 2005, 2010 ve 2012-2019 arası "yarı kurak-nemli arası" iklim tipi gözlemlenmiştir. Çalışma alanında 1990-2020 yılları arası genel ortalama indis değerleri dikkate alındığında ise 11.60 indis değeriyle "yarı kurak-nemli arası" iklim tipinin hakim olduğu görülmektedir (Şekil 2).

Eğirdir ilçesi için Çizelge 3 incelendiğinde, "yarı kuraknemli arası" ve "yarı nemli" iklim sınıflarına rastlanılmıştır. Yarı kurak-nemli arası iklim sınıfinın 1990, 1992-1994 aras1, 1997, 1999-2000 aras1, 2004, 2007-2008 aras1, 2010-2013 arası, 2016-2018 arası ve 2020 yıllarında hakim olduğu belirlenmiştir. Yarı nemli iklim sınıfının ise 1991, 1995-1996 aras1, 1998, 2001-2003 aras1, 2005-2006 aras1, 2009, 20142015 arası ve 2019 yıllarında olduğu belirlenmiştir. Çalışma alanında 1990-2020 yılları arası genel ortalamasının 18.97 indis değeriyle "yarı kurak-nemli arası" iklim tipinin hakim olduğu görülmektedir (Şekil 2). Aktaş vd. (2018) tarafından Eğirdir Gölü havzasında yapılan çalışmada iklim özelliğinin yarı kurak-nemli arası olduğu ortaya koyulmuştur. Bu sonuçların çalışmamızla benzerlik gösterdiği söylenebilir.

Isparta (Merkez) için Çizelge 3 incelendiğinde, "yarı kurak" ve "yarı kurak-nemli arası" iklim sinıfları tespit edilmiştir. Yarı kurak iklim sınıfının 1990, 1993, 1999, 2011 ve 2019-2020 yılları arasında, yarı kurak-nemli arası iklim sınıfinın ise 1991-1992 arası, 1994-1998 aras1, 2000-2010 arası ve 2012-2018 yıllarında hakim olduğu belirlenmiştir. Çalışma alanında 1990-2020 yılları arası genel ortalamasının 13.32 indis değeriyle "yarı kurak-nemli arası" iklim tipinin hakim olduğu görülmektedir (Şekil 2). Bu sonuçlar, MGM (2016)'nin Isparta ili için belirlediği iklim özellikleri ile benzerlik göstermektedir.

Elde edilen indis değerlerine (Ia) göre Uluborlu, Senirkent ve Yalvaç istasyonları için 1990-2020 yılları aralığında yapılan sınıflandırma Çizelge 4'de, bu indis değerlerine karşılık gelen iklim sınıflandırma grafiği ise Şekil 3 'de verilmiştir.

Senirkent ilçesi için Çizelge 4 incelendiğinde "yarı kuraknemli arası", "yarı nemli" ve "nemli" iklim sınıflarına rastlanılmıştır. Yarı kurak-nemli arası iklim sınıfının 19931994 aras1, 1996-1997 aras1, 2002, 2008 ve 2016 y1llarında hakim olduğu belirlenmiştir. Yarı nemli iklim sınıfının 19901992 aras1, 1995, 1999-2001 aras1, 2004, 2007, 2009, 20122013 arası, 2015 ve 2017-2020 yıllarında hakim olduğu saptanmıştır. Nemli iklim sınıfi ise 1998, 2003, 2006 arası, 2010-2011 arası ve 2014 yıllarında gözlemlenmiştir. Çalışma alanında 1990-2020 ortalaması olan 23.96 indis değeriyle genel olarak "yarı nemli" iklim tipinin hakim olduğu görülmektedir (Şekil 3). MGM (2016)'nin Senirkent ilçesi için belirlediği iklim özelliği ile sonuçlarımız arasında küçük farklılıklar görülmekte olup, bu farklılıkların oluşmasında çalışmanın yürütüldüğü zaman periyodundaki yıllık ortalama yağış ve sıcaklık değerlerinin etkili olduğu söylenebilir.
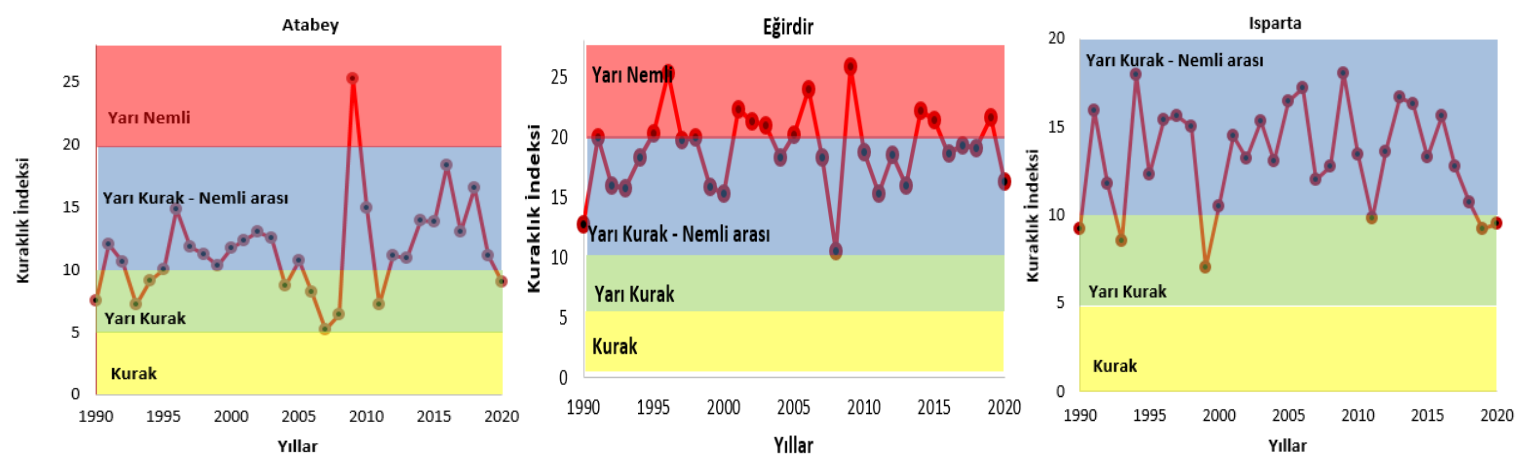

Şekil 2. De Martonne yöntemine göre Atabey, Eğirdir ve Isparta (Merkez) iklim sınıflandırma grafiği

Çizelge 4. De Martonne yöntemine göre Senirkent, Uluborlu ve Yalvaç'ın kuraklık indis değerleri

\begin{tabular}{|c|c|c|c|c|c|c|c|c|c|c|c|c|c|}
\hline & \multicolumn{2}{|c|}{ Uluborlu } & \multicolumn{2}{|c|}{ Senirkent } & \multicolumn{2}{|c|}{ Yalvaç } & & \multicolumn{2}{|c|}{ Uluborlu } & \multicolumn{2}{|c|}{ Senirkent } & \multicolumn{2}{|c|}{ Yalvaç } \\
\hline Y1l & Ia & Sinıf & Ia & Sinıf & Ia & Sinif & Y1l & Ia & Sinıf & Ia & Sinif & Ia & Sinif \\
\hline 1990 & 8.54 & YK & 20.30 & YN & 9.15 & YK & 2005 & 17.95 & YK-NA & 17.54 & YK-NA & 12.24 & YK-NA \\
\hline 1991 & 19.35 & YK-NA & 24.52 & YN & 20.48 & YN & 2006 & 16.18 & YK-NA & 30.10 & $\mathrm{~N}$ & 8.97 & YK \\
\hline 1992 & 13.65 & YK-NA & 24.91 & YN & 13.92 & YK-NA & 2007 & 11.73 & YK-NA & 26.76 & YN & 5.30 & YK \\
\hline 1993 & 17.77 & YK-NA & 19.41 & YK-NA & 9.56 & YK & 2008 & 10.14 & YK-NA & 16.63 & YK-NA & 7.90 & YK \\
\hline 1994 & 27.08 & YN & 17.29 & YK-NA & 16.87 & YK-NA & 2009 & 17.33 & YK-NA & 25.11 & YN & 5.75 & YK \\
\hline 1995 & 15.49 & YK-NA & 22.76 & YN & 17.02 & YK-NA & 2010 & 14.80 & YK-NA & 30.49 & $\mathrm{~N}$ & 13.06 & YK-NA \\
\hline 1996 & 35.10 & ÇN & 18.65 & YK-NA & 22.58 & YN & 2011 & 12.87 & YK-NA & 28.30 & $\mathrm{~N}$ & 9.49 & YK \\
\hline 1997 & 14.17 & YK-NA & 19.19 & YK-NA & 17.91 & YK-NA & 2012 & 12.26 & YK-NA & 24.28 & YN & 10.67 & YK-NA \\
\hline 1998 & 14.81 & YK-NA & 31.71 & $\mathrm{~N}$ & 13.35 & YK-NA & 2013 & 11.20 & YK-NA & 20.05 & YN & 12.74 & YK-NA \\
\hline 1999 & 18.19 & YK-NA & 26.10 & YN & 22.42 & YN & 2014 & 19.62 & YK-NA & 30.35 & $\mathrm{~N}$ & 15.22 & YK-NA \\
\hline 2000 & 14.63 & YK-NA & 29.55 & YN & 12.05 & YK-NA & 2015 & 22.46 & YN & 25.62 & YN & 20.49 & YN \\
\hline 2001 & 19.07 & YK-NA & 25.13 & YN & 18.39 & YK-NA & 2016 & 21.62 & YN & 18.55 & YK-NA & 10.88 & YK-NA \\
\hline 2002 & 29.11 & $\mathrm{~N}$ & 17.09 & YK-NA & 15.60 & YK-NA & 2017 & 17.53 & YK-NA & 22.76 & YN & 12.68 & YK-NA \\
\hline 2003 & 17.17 & YK-NA & 28.72 & $\mathrm{~N}$ & 16.65 & YK-NA & 2018 & 14.70 & YK-NA & 27.03 & YN & 11.13 & YK-NA \\
\hline 2004 & 11.06 & YK-NA & 24.96 & YN & 16.06 & YK-NA & 2019 & 10.09 & YK-NA & 22.25 & YN & 13.00 & YK-NA \\
\hline & & & & & & & 2020 & 9.04 & YK & 26.57 & YN & 6.80 & YK \\
\hline
\end{tabular}

Kurak: K, Yarı Kurak: YK, Yarı Kurak -Nemli Arası: YK-NA, Yarı Nemli: YN, Nemli: N, Çok Nemli: ÇN, Islak: I 
Uluborlu ilçesi için Çizelge 4 incelendiğinde, "yarı kurak", "yarı kurak-nemli arası", "yarı nemli”, "nemli" ve "çok nemli" iklim sınıfları tespit edilmiştir. Yarı kurak iklim sınıfının sadece 1990 ve 2020 yıllarında hakim olduğu belirlenmiştir. Yarı kurak-nemli arası iklim sınıfı 1991-1993 aras1, 1995, 1997-2001 aras1, 2003-2014 aras1 ve 2017-2019 yıllarında gözlemlenmiştir. Yarı nemli iklim sınıfının 20152016 yılları arasında, nemli iklim sınıfinın sadece 2002 yılında, çok nemli iklim sınıfının ise sadece 1996 yılında olduğu tespit edilmiştir. Çalışma alanında 1990-2020 ortalaması olan 16.60 indis değeriyle "yarı kurak-nemli arası" iklim tipinin hakim olduğu görülmektedir (Şekil 3). Bu sonuçlar, MGM (2016)'nin Uluborlu ilçesi için belirlediği iklim özelliği ile benzerlik göstermektedir.

Yalvaç ilçesi için Çizelge 4 incelendiğinde, "yarı kurak", "yarı kurak-nemli arası" ve "yarı nemli" iklim sınıfları tespit edilmiştir. Yarı kurak iklim sınıfının 1990, 1993, 2006-2009 arası, 2011 ve 2020 yıllarında hakim olduğu belirlenmiştir. Yarı kurak-nemli arası iklim sınıfinın 1992, 1994-1995 arası, 1997-1998 arası, 2000-2005 arası, 2010, 2012-2014 arası ve 2016-2019 yıllarında olduğu saptanmıştır. İlçede 1991, 1996, 1999 ve 2015 yıllarında "yarı nemli" iklim sınıfi gözlemlenmiştir. Ayrıca çalışma alanında 1990-2020 ortalaması olan 13.49 indis değeriyle genel olarak "yarı kurak-nemli arası" iklim tipinin hakim olduğu görülmektedir (Şekil 3). Bu sonuçlarda MGM (2016)'nin Yalvaç ilçesi için belirlediği iklim özelliği ile benzerlik göstermektedir.

\subsection{Standart Yă̆ış İndeksi (SYI)}

SYİ analizleri, araştırmada kullanılan zaman dilimine göre farklılık göstermektedir. 1 aylık SYİ değerleri toprak nemi ile ilgili olabilecek kısa vade için kuraklık durumunu göstermekte olup, 3 aylık SYÍler mevsimsel yağış tahmininde, 6 ve 9 aylık SYI'ler yağış koşullarında meydana gelen mezo-ölçek eğilimleri göstermektedir (Wu vd., 2001). Son olarak, 12 aylık SYİ indis değerleri ise uzun vadeli yağışlardaki farklılıkları ortaya koymaktadır (Karabulut, 2020). Isparta ili için yapılan SYİ kuraklık analizinde, kuraklık indis değerlerinin hesaplanmasıyla analizi yapılan 6 istasyonda bu değerlerin zamana bağlı değişimi çizelge ve grafikler halinde aşağıda verilmiştir.

Atabey, Eğirdir ve Isparta (Merkez) meteoroloji istasyonlarına ait yağış verileri kullanılarak SYİ yöntemi ile istasyonlara ait bölgelerin kuraklık analizleri yapılmıştır. İstasyonlara ait SYİ değerleri Çizelge 2'ye göre değerlendirilmiş olup, yüzde dağılımı olarak Çizelge 5 'de verilmiştir. Atabey ilçesinde çok şiddetli kuraklık, şiddetli kuraklık, orta şiddetli kuraklık, normale yakın kuraklık oluşum yüzdeleri 1 aylık SYİ değerine göre sırasıyla \%1.9, $\% 0.0, \% 8.1, \% 38.5 ; 3$ aylık SYİ değerine göre sırasıyla \%1.8, $\% 4.8, \% 6.2, \% 34.4 ; 6$ aylık SYİ değerine göre sırasıyla $\% 3.2$, $\% 1.9, \% 6.0, \% 32.7 ; 9$ aylık SYİ değerine göre sirasıyla $\% 3.2$, $\% 2.4, \% 4.6, \% 30.7$ ve 12 aylı SYİ değerine göre sirasıly \%3.3, \%2.2, \%1.9, \%32.4 olarak hesaplanmıştır (Çizelge 5).
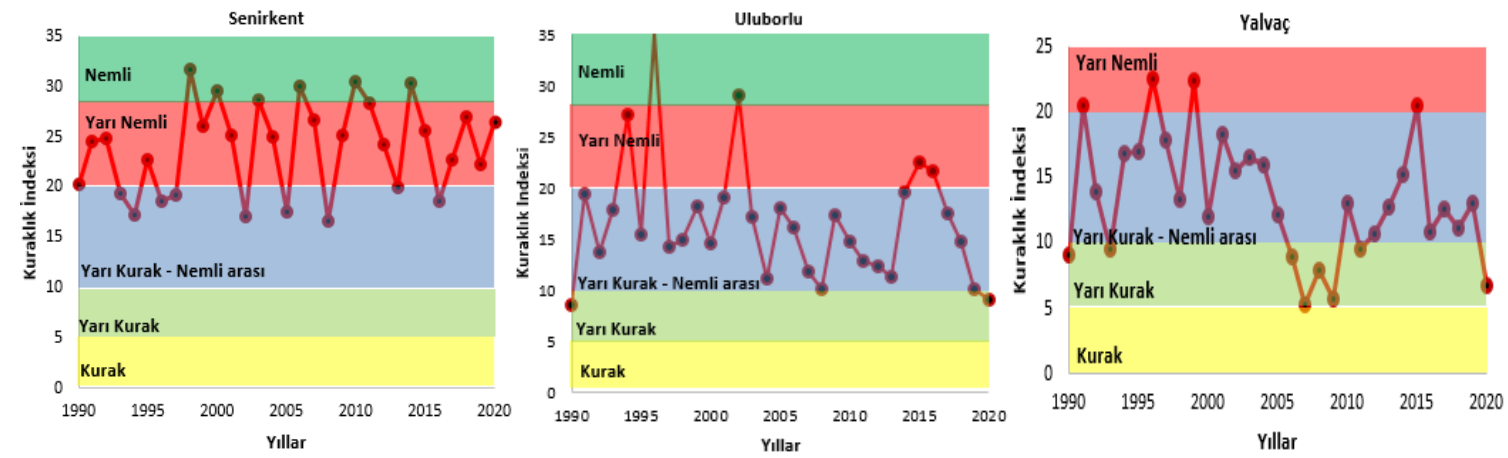

Şekil 3. De Martonne yöntemine göre Senirkent, Uluborlu ve Yalvaç iklim sınıflandırma grafiği

Çizelge 5. SYİ yöntemine göre Atabey, Eğirdir ve Isparta (Merkez)'e ait kuraklık oluşum yüzdeleri

\begin{tabular}{|c|c|c|c|c|c|c|c|c|c|c|c|c|c|c|c|}
\hline \multirow{2}{*}{ 空莺 } & \multicolumn{3}{|c|}{1 Aylık SYİ (\%) } & \multicolumn{3}{|c|}{3 Aylık SYİ (\%) } & \multicolumn{3}{|c|}{6 Aylık SYİ $(\%)$} & \multicolumn{3}{|c|}{9 Aylık SYİ (\%) } & \multicolumn{3}{|c|}{ 12Aylık SYİ (\%) } \\
\hline & $\begin{array}{l}\vec{\circlearrowright} \\
\frac{\mathbb{\pi}}{\pi}\end{array}$ & 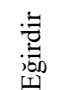 & 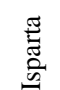 & $\begin{array}{l}\text { ঠे } \\
\frac{0}{\pi} \\
\frac{\pi}{4}\end{array}$ & 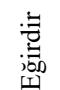 & 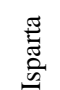 & 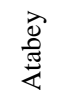 & : & 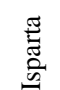 & $\begin{array}{l}\text { बे } \\
\frac{\mathbb{\Xi}}{4}\end{array}$ & 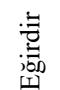 & 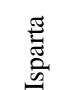 & $\begin{array}{l}\text { बे } \\
\frac{\pi}{\pi}\end{array}$ & : & 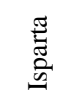 \\
\hline ÇŞY & 3.3 & 0.8 & 3.2 & 0.8 & 1.6 & 2.7 & 0.2 & 1.0 & 2.1 & 0 & 1.1 & 2.4 & 0 & 1.9 & 2.5 \\
\hline ÇY & 3.0 & 5.3 & 1.8 & 4.0 & 3.2 & 3.2 & 2.1 & 3.5 & 5.4 & 1.6 & 4.9 & 6.0 & 1.6 & 1.6 & 5.0 \\
\hline OŞY & 10.8 & 10.2 & 10.2 & 9.7 & 10.8 & 8.9 & 10.9 & 11.2 & 11.2 & 9.8 & 12.3 & 9.6 & 9.1 & 14.1 & 10.8 \\
\hline $\mathrm{N}$ & 34.0 & 35.4 & 35.4 & 37.9 & 39.2 & 35.9 & 42.6 & 37.7 & 27.3 & 47.2 & 33.6 & 31.9 & 49.3 & 35.0 & 29.1 \\
\hline NYK & 38.5 & 33.0 & 34.4 & 34.4 & 29.5 & 33.7 & 32.7 & 29.7 & 39.3 & 30.7 & 30.5 & 34.1 & 32.4 & 29.4 & 35.8 \\
\hline OŞK & 8.1 & 9.1 & 8.0 & 6.2 & 7.3 & 8.6 & 6.0 & 8.1 & 6.8 & 4.6 & 8.8 & 9.9 & 1.9 & 8.0 & 11.3 \\
\hline ŞK: & 0 & 2.6 & 4.3 & 4.8 & 4.0 & 4.0 & 1.9 & 4.9 & 6.0 & 2.4 & 5.5 & 3.5 & 2.2 & 7.7 & 3.3 \\
\hline ÇŞKK & 1.9 & 3.2 & 2.4 & 1.8 & 4.0 & 2.7 & 3.2 & 3.5 & 1.6 & 3.2 & 3.0 & 2.2 & 3.3 & 1.9 & 1.9 \\
\hline
\end{tabular}

ÇŞY: Çok Şiddetli Yağışlı, ÇY: Çok Yağışlı, OŞY: Orta Şiddetli Yağışlı, N: Normal, NYK: Normale Yakın Kuraklık, OŞK: Orta Şiddetli Kuraklık, ŞK: Şiddetli Kuraklık, ÇŞK: Çok Şiddetli Kuraklık 
Atabey ilçesine ait veriler kullanılarak elde edilen 1, 3, 6, 9, 12 aylık SYİ grafikleri Şekil 4'de verilmiştir. Buna göre kuraklığın en uzun olduğu dönemler; 1 aylık SYİ için 2007 Ağustos ile 2008 Temmuz arasında 12 ay, 3 aylık SYİ'ye bakıldığında 2007 Ocak ile 2008 Ağustos arasında 20 ay, 6 aylık SYİ incelendiğinde 2007 Nisan ile 2008 Ekim arasında 19 ay, 9 aylık SYİ için 1992 Aralık ile 1995 Şubat arasında 27 ay, 12 aylık SYİ değerine göre ise 1992 Aralık ile 1995 Şubat arasında 27 ay olarak görülmektedir.

Eğirdir ilçesinde çok şiddetli kuraklık, şiddetli kuraklık, orta şiddetli kuraklık, normale yakın kuraklık yüzdeleri 1 aylık SYİ için sırasıyla \%3.2, \%2.6, \%9.1, \%33.0; 3 aylık SYİ değerine göre sirasıyla $\% 4.0, \% 4.0, \% 7.3, \% 29.5 ; 6$ aylık SYİ değerine göre sırasıyla $\% 3.5, \% 4.9, \% 8.1, \% 29.7 ; 9$ aylık SYİ değerine göre sirasiyla \%3.0, \%5.5, \%8.8, \%30.5; 12 aylık SYİ değerine göre sırasıyla \%1.9, \%7.7, \%8.0 \%29.4 olarak hesaplanmıştır (Çizelge 5). Eğirdir ilçesine ait veriler kullanılarak elde edilen 1, 3, 6, 9, 12 aylık SYİ grafikleri Şekil 5'de verilmiş olup, Şekil 5'e göre kuraklığın en uzun olduğu dönemler; 1 aylık SYİ değerinde 2008 Ocak ile 2008 Temmuz arasında 7 ay, 3 aylık SYİ değerinde 1993 Mayıs ile 1994 Haziran arasında 14 ay, 6 aylık SYİ değerini incelediğimizde 1999 Mayıs ile 2001 Ağustos arasında 28 ay, 9 aylık SYİ için 1999 Mayıs ile 2001 Ekim arasında 30 ay, 12 aylık SYİ değerine bakıldığında 1999 Mayıs ile 2001 Kasım arasında 31 ay olarak görülmektedir.
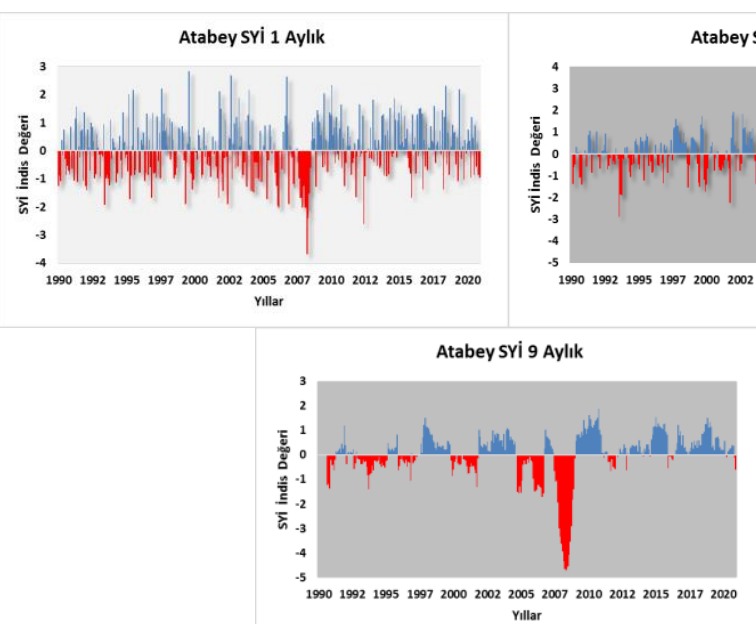

Atabey SYi 3 Aylik

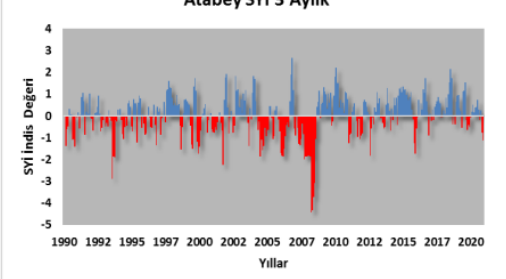

Atabey SYi 6 Aylık

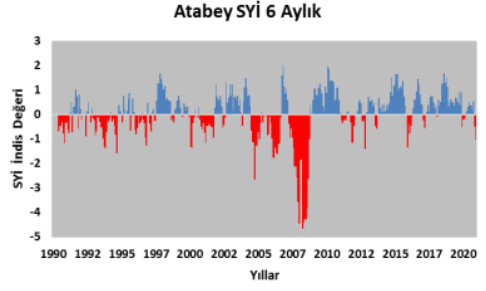

Atabey SYi 12 Aylık

Şekil 4. Atabey ilçesine ait 1, 3, 6, 9, 12 aylık SYİ zaman serileri

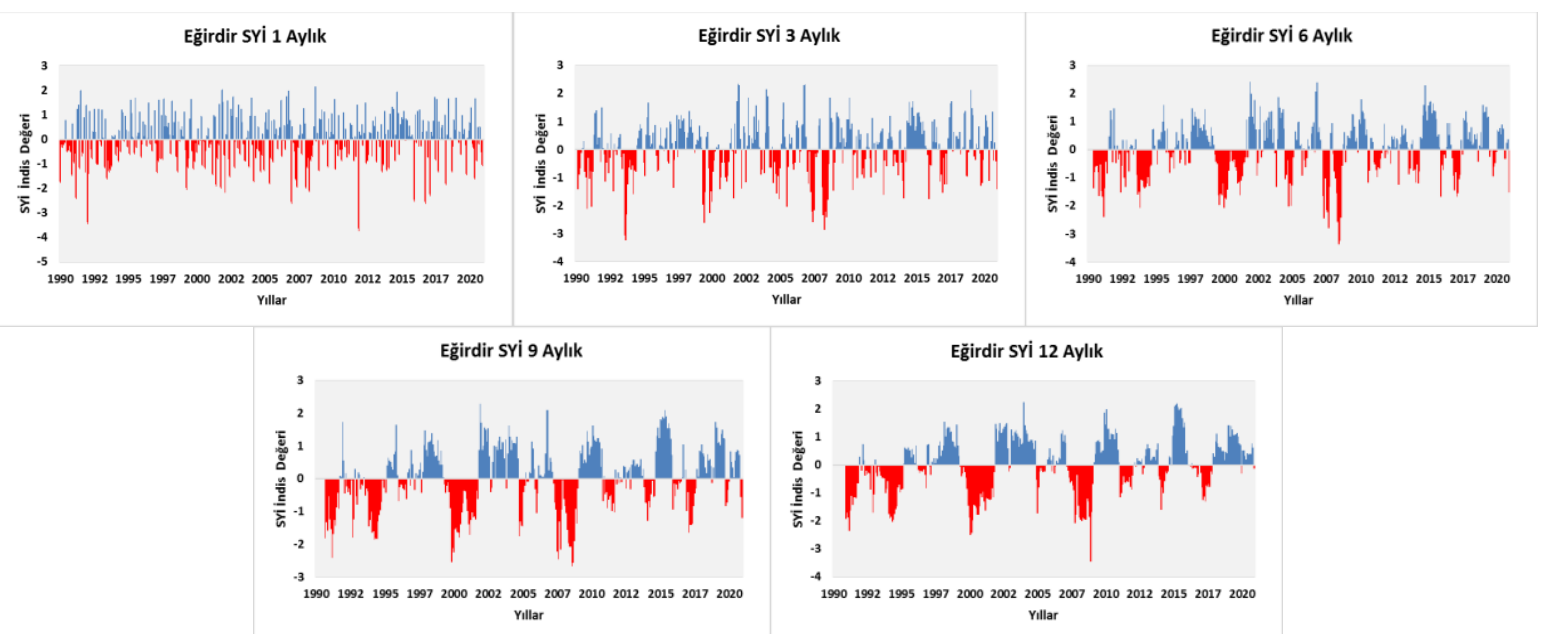

Şekil 5. Eğirdir ilçesine ait 1, 3, 6, 9, 12 aylık SYİ zaman serileri 
Isparta (Merkez)'e ait çok şiddetli kuraklık, şiddetli kuraklık, orta şiddetli kuraklık, normale yakın kuraklık yüzdeleri 1 aylık SYİ değerine göre sirasıyla \%2.4, \%4.3, $\% 8.0, \% 34.4 ; 3$ aylık SYİ değerine göre sirasıyla \%2.7, \%4.0, $\% 8.6, \% 33.7 ; 6$ aylık SYİ değerine göre sirasıyla \%1.6, \%6.0, $\% 6.8, \% 39.3$; 9 aylık SYİ değerine göre sirasıly $\% 2.2, \% 3.5$, $\% 9.9, \% 34.1 ; 12$ aylık SYİ değerine göre sirasiyla \%1.9, \%3.3, \%11.3, \%35.8 olarak hesaplanmıştır (Çizelge 5). Isparta (Merkez) istasyonunun verilerinden yararlanilarak elde edilen 1, 3, 6, 9, 12 aylık SYİ grafikleri Şekil 6'da verilmiştir. Buna göre kuraklığın en uzun olduğu dönemler; 1 aylık SYİ değerinde 1999 Eylül ile 2000 Mart ve 2019 Temmuz ile 2020 Ocak tarihleri arasında 7 ay, 3 aylık SYI için 2001 Ocak ile 2001 Ekim ve 2004 Nisan ile 2005 Ocak arasında ve 2007 Ocak ile 2007 Ekim yılları arasında 10 ay, 6 aylık SYİ değerinde 1999 Mayıs ile 2001 Ekim arasında 30 ay, 9 aylık SYİ değeri için 1999 Mayıs ile 2001 Ekim arasında 30 ay, 12 aylık SYİ değerine bakıldığında 1999 Mayıs ile $2001 \mathrm{Kasım}$ arasında 31 ay olarak görülmektedir. Ülkemizde SYİ yöntemi Topçu ve Karaçor (2021), Özfidaner ve Topaloğlu (2020) ve Karabulut (2020) gibi araştırmacılar tarafından da kullanılmıştır. Bununla birlikte yine bu konuda çalışmalar yürüten Uçar vd. (2019)'nin Isparta ilinin kuraklık durumunu belirledikleri çalışmada Atabey, Eğirdir ve Isparta için kuraklık sonuçlarının bulgularımız ile benzerlik gösterdiği görülmektedir. Yine araştırmalarında kurak sınıflar arasında normale yakın kuraklık görülen ayların sayısının diğer kuraklık sinıflarına göre fazla olduğunu belirtmişlerdir. $\mathrm{Bu}$ durum da araştırmamızla benzerlik göstermektedir. Atabey, Eğirdir ve Isparta'da SYİ sınıflarının dağılımlarına bakıldığında da benzer bulgular tespit edilmiştir.

Senirkent, Uluborlu ve Yalvaç meteoroloji istasyonlarına ait yağış verilerinin değerlendirilmesiyle yapılan SYİ hesaplamaları sonucunda elde edilen SYİ değerleri Çizelge 2'deki kuraklık sınıflandırmasına göre sınıflandırılmış olup, yüzde dağılımları Çizelge 6'da verilmiştir.

Senirkent ilçesinde çok şiddetli kuraklık, şiddetli kuraklık, orta şiddetli kuraklık, normale yakın kuraklık oluşum yüzdeleri 1 aylık SYİ değerine göre sırasıyla \%2.6, $\% 3.2, \%$ 9.9, \%33.3; 3 aylık SYİ değerine göre sırasıyla $\% 2.4, \% 3.8, \% 9.7, \% 35.3 ; 6$ aylık SYİ değerine göre sirasiyla \%2.4, \%3.2, \% 10.9, \%34.1; 9 aylı SYİ değerine göre sirasiyla $\% 2.1, \% 3.2, \% 11.5, \% 34.6$ ve 12 aylık SYİ değerine göre sirasiyla \%0.8, \%4.1, \%13.0, \%33.4 olarak hesaplanmıştır (Çizelge 6). Senirkent ilçesinde bulunan istasyona ait verilerden üretilmiş 1, 3, 6, 9, 12 aylık SYİ grafikleri Şekil 7'de verilmiştir. Şekil 7'ye göre kuraklığın en uzun olduğu dönemlere bakıldığında, 1 aylık SYİ değeri için 2004 Mayıs ile 2004 Ekim arasında ve 2005 Mayıs ile 2005 Ekim yılları arasında 6 ay, 3 aylık SYİ için 2000 Ağustos ile 2001 Ekim arasında 15 ay, 6 aylık SYİ için 1992 Kasım ile 1994 Ekim arasında 24 ay, 9 aylık SYİ için 1992 Aralık ile 1994 Ekim arasında 23 ay, 12 aylık SYİ değerine bakıldığında 1992 Ekim ile 1994 Eylül arasında ve 2000 Ocak ile 2001 Aralık arasında 20 ay sürmüş olduğu görülmektedir.
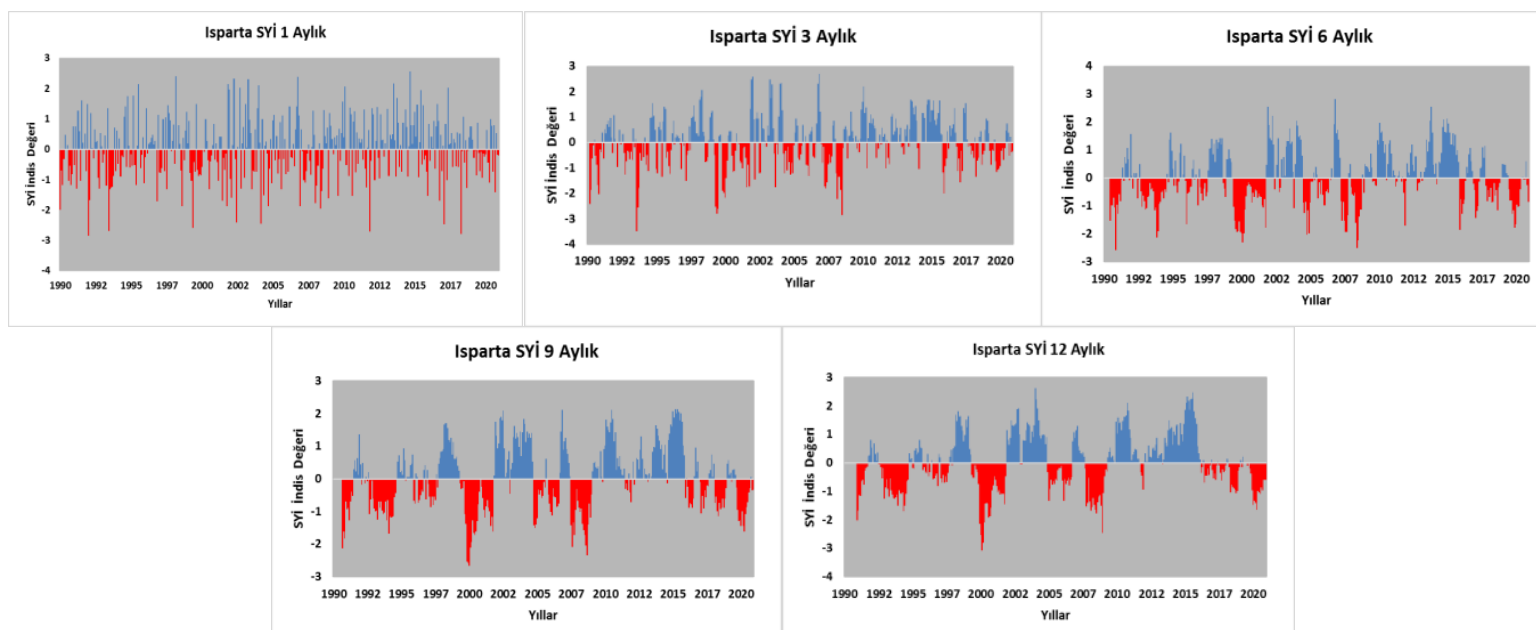

Şekil 6. Isparta (Merkez) ait 1, 3, 6, 9, 12 aylık SYİ zaman serileri

Çizelge 6. SYİ yöntemine göre Senirkent, Uluborlu ve Yalvaç'a ait kuraklık oluşum yüzdeleri

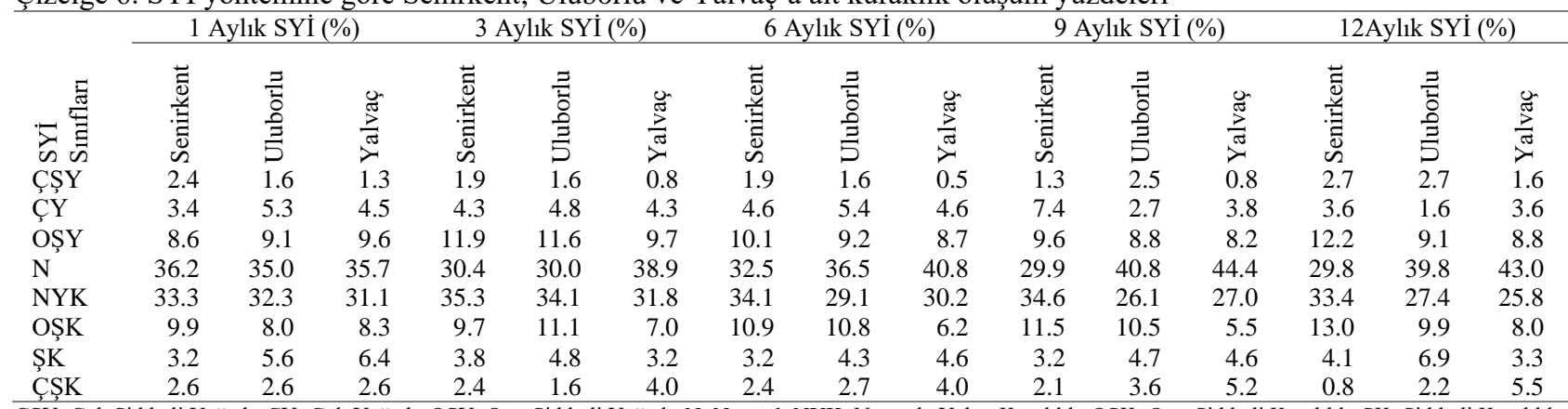

ÇŞY: Çok Şiddetli Yağışlı, ÇY: Çok Yağış̧lı, OŞY: Orta Şiddetli Yağışı, N: Normal, NYK: Normale Yakın Kuraklık, OŞK: Orta Şiddetli Kuraklık, ŞK: Şiddetli Kuraklık, ÇŞK: Çok Şiddetli Kuraklık 
Uluborlu ilçesinde çok şiddetli kuraklık, şiddetli kuraklık, orta şiddetli kuraklık, normale yakın kuraklık oluşum yüzdeleri 1 aylık SYİ değerine göre sirasıyla \%2.6, \%5.6, $\% 8.0, \% 32.3 ; 3$ aylık SYİ değerine göre sirasıyla $\% 1.6, \% 4.8$, $\% 11.1, \% 34.1 ; 6$ aylık SYİ değerine göre sirasıly \%2.7, $\% 4.3, \% 10.8, \% 29.1 ; 9$ aylık SYİ değerine göre sirasiyla \%3.6, \%4.7, \%10.5, \%26.1 ve 12 aylı SYİ değerine göre sırasıyla \%2.2, \%6.9, \%9.9, \%27.4 olarak hesaplanmıştır (Çizelge 6). Uluborlu ilçesinde bulunan istasyona ait verilerden elde edilen 1, 3, 6, 9, 12 aylık SYİ grafikleri Şekil 8'de verilmiştir. Şekil 8'de kuraklığın en uzun olduğu dönemler; 1 aylık SYİ değeri için 1989 Aralık ile 1990 Nisan arasında ve 1998 Mayıs ile 1998 Eylül arasında 5 ay, 3 aylık SYİ için 2013 Nisan ve 2014 Nisan arasında 13 ay, 6 aylık SYİ için 2004 Temmuz ile 2006 Mart arasında 21ay, 9 aylık SYİ değeri için 2004 Eylül ile 2006 Ağustos arasında 24 ay, 12 aylık SYİ değerine bakıldığında 2012 Mart ile 2014 Ağustos arasında 30 ay olarak görülmektedir.

Yalvaç ilçesinde çok şiddetli kuraklık, şiddetli kuraklık, orta şiddetli kuraklık, normale yakın kuraklık oluşum yüzdeleri 1 aylık SYİ değerine göre sirasıyla \%2.6, \%6.4, $\% 8.3, \% 31.1 ; 3$ aylık SYİ değerine göre sirasıyla $\% 4.0, \% 3.2$, $\% 7.0, \% 31.8 ; 6$ aylık SYİ değerine göre sirasıyla $\% 4.0, \% 4.6$, $\% 6.2, \% 30.2$; 9 aylık SYİ değerine göre sirasıyla $\% 5.2, \% 4.6$, $\% 5.5, \% 27.0$ ve 12 aylık SYİ değerine göre sırasılla \%5.5,
\%3.3, \%8.0, \%25.8 olarak hesaplanmıștır (Çizelge 6). Yalvaç ilçesi meteoroloji istasyonuna ait verilerden elde edilen 1, 3, 6, 9, 12 aylık SYİ grafikleri Şekil 9'da verilmiştir. Şekil 9'da kuraklığın en uzun olduğu dönemler incelendiğinde, 1 aylık SYİ değeri için 2009 Mart ile 2009 Ekim arasında 8 ay, 3 aylık SYİ için 2005 Temmuz ile 2006 Ağustos arasında 14 ay, 6 aylık SYİ için 1992 Ocak ile 1994 Mart arasında ve 2019 Ekim ile 2020 Aralık arasında 15 ay, 9 aylık SYİ için 2006 Aralık ile 2009 Ocak arasında 38 ay, 12 aylık SYI değerine bakıldığında 2004 Eylül ile 2010 Mart arasında 67 ay sürmüş olduğu görülmektedir.

Uçar vd. (2019)'nin Senirkent, Uluborlu ve Yalvaç ilçelerine ait kuraklık sonuçlarıyla bulgularımızın benzerlik gösterdiği söylenebilir. Bununla birlikte yapılan araştırmada kurak sınıflar arasında normale yakın kuraklık görülen ayların sayısının diğer kuraklık sınıflarına göre daha fazla olduğu belirtilmiştir. Bu durum da araştırmamızdaki sonuçlar ile uyumludur. Senirkent, Uluborlu ve Yalvaç ilçelerine ait SYİ sınıflarının dağılımlarına bakıldığında da benzer bulgular görülmektedir.

Kurnaz (2014) tarafından yapılan çalışmada Türkiye'nin 2007-2008 ile 2013-2014 dönemlerinin kurak geçtiği bildirilmiş olup, bu durumun araştırmamızla (Senirkent, Uluborlu ve Yalvaç istasyonları için) benzerlik gösterdiği söylenebilir.

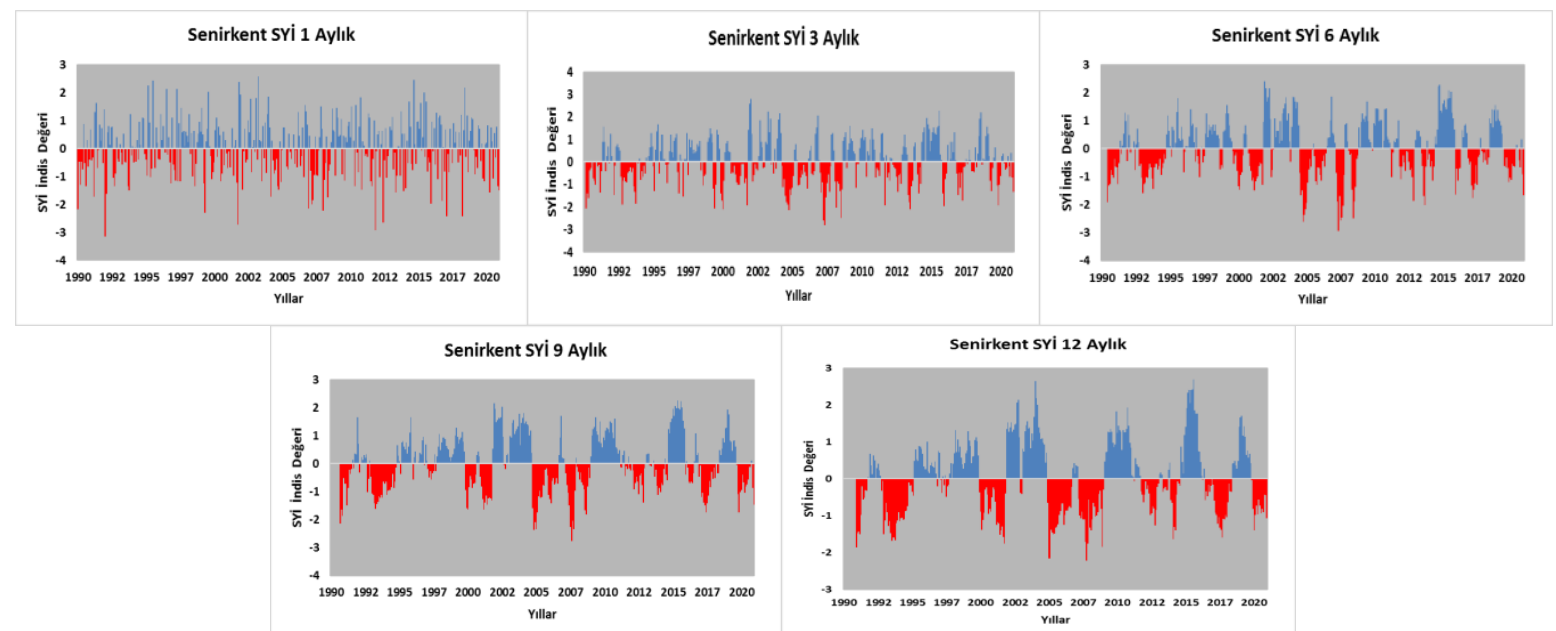

Şekil 7. Senirkent ilçesine ait 1, 3, 6, 9, 12 aylık SYİ zaman serileri 

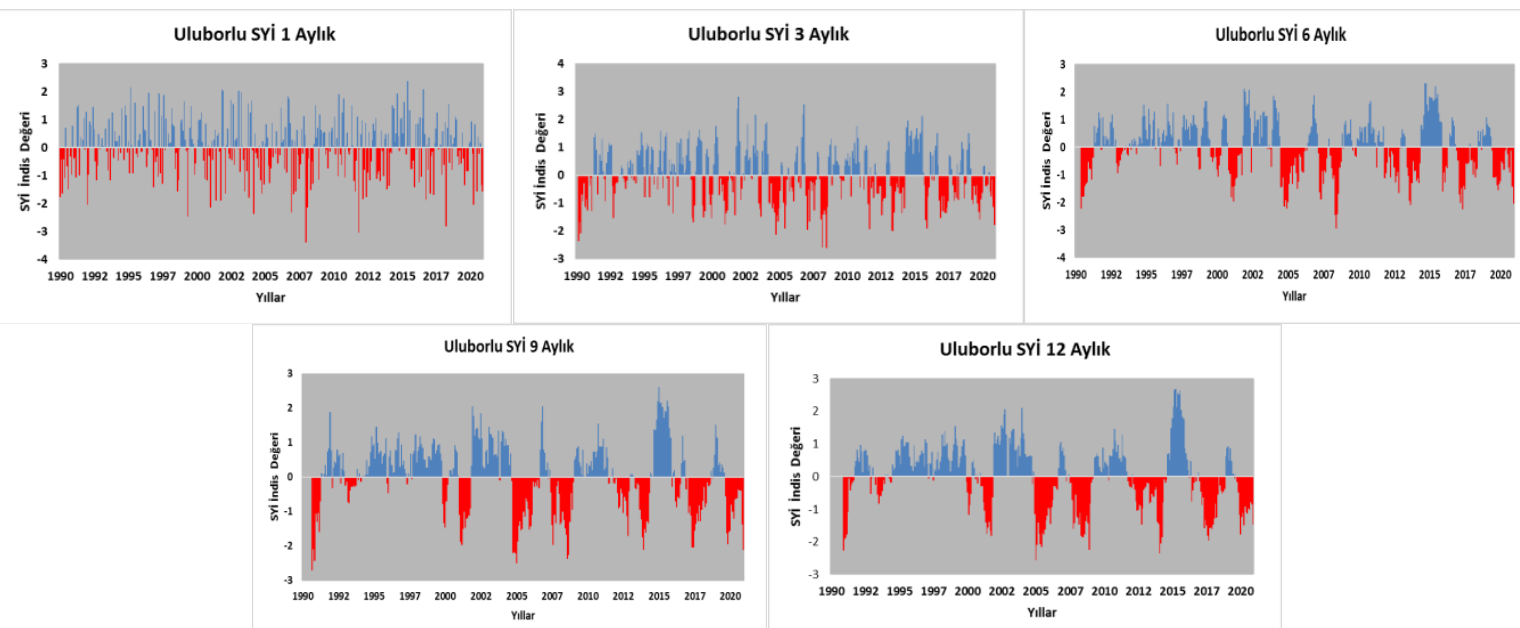

Şekil 8. Uluborlu ilçesine ait 1, 3, 6, 9, 12 aylık SYİ zaman serileri
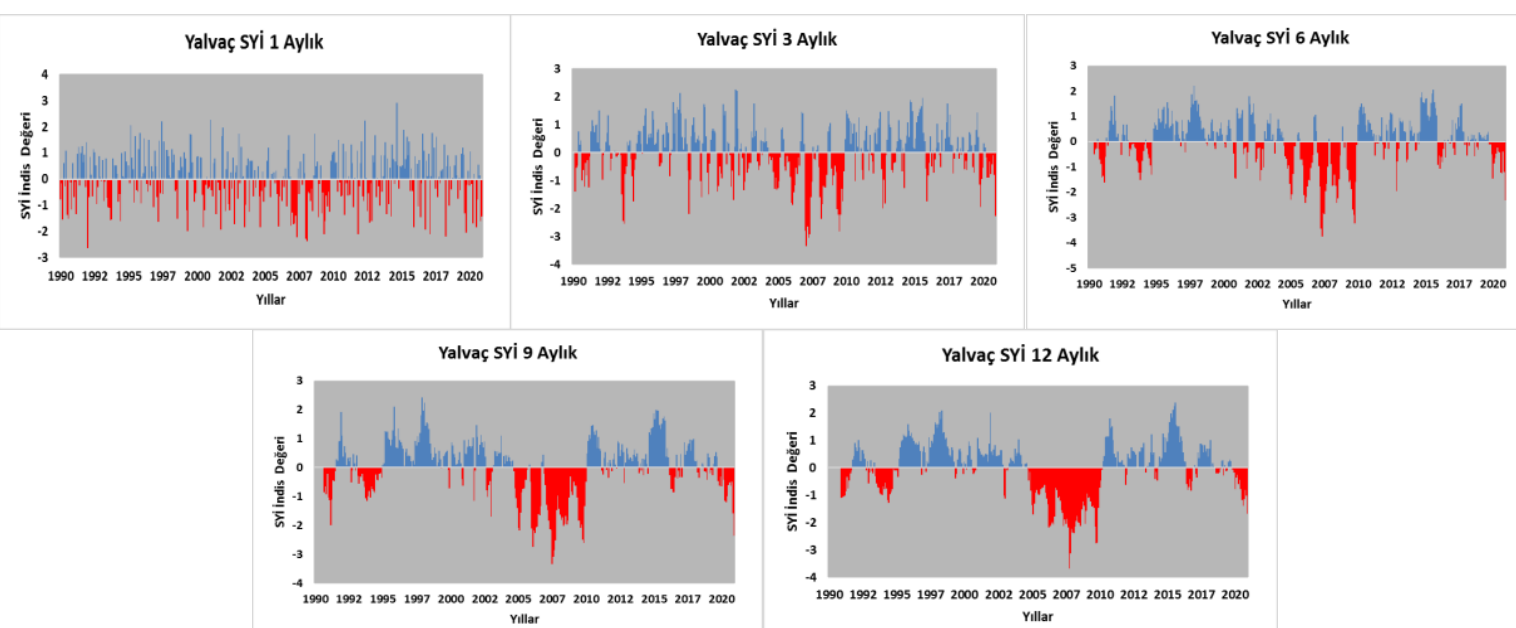

Şekil 9. Yalvaç ilçesine ait 1, 3, 6, 9, 12 aylık SYİ zaman serileri

\section{Sonuç}

Isparta ilinde kuraklık analizi ve kuraklı̆̆ı izlenmesi amacıyla yapılmış olan çalışmada, De Martonne-Gottman yöntemine göre yapılan değerlendirmeler sonunda 19902020 iklim periyodu için yıllık bazda hangi istasyonların hangi yllda kurak veya nemli olduğu ortaya konulmuştur. $\mathrm{Bu}$ bağlamda genel olarak kuraklık indis değerlerine göre yapılan kuraklık sınıflandırılmasına bakıldığında Atabey, Eğirdir, Isparta (Merkez), Uluborlu ve Yalvaç ilçelerinin "step (yarı kurak)-nemli" arası iklim tipinde olduğu tespit edilirken, Senirkent ilçesinin "yarı nemli" iklim tipinde olduğu tespit edilmiştir. SYİ yöntemine göre yapılan değerlendirmeler sonunda araştırma alanına ait 1990-2020 yılları arasındaki yağış verileri kullanılarak 1, 3, 6, 9 ve 12 aylık periyotlarda kuraklık sinıfları için olasılıklar belirlenmiştir. Belirlenen olasılıklar incelendiğinde araştırma alanının genelinde "normale yakın kuraklık" döneminin hakim olduğu görülmektedir. Şiddetli ve çok şiddetli dönemlerin ise çok seyrek olduğu görülmüştür. SYİ 12 aylık değerleri incelendiğinde kuraklığın; Atabey istasyonunda 27 ay (Aralık 1992 - Şubat 1995), Eğirdir istasyonunda 31 ay (Mayıs 1999 - Kasım 2001), Isparta (Merkez) istasyonunda 31 ay (Mayıs 1999 - Kasım 2001), Senirkent istasyonunda 20 ay (Ekim 1992 - Eylül 1994 ve Ocak 2000 - Aralık 2001), Uluborlu istasyonunda 30 ay (Mart 2012 - Ağustos 2014) ve Yalvaç istasyonunda ise 67 ay (Eylül 2004 - Mart 2010) sürdüğü tespit edilmiştir. Değerlendirilen dönemde 12 aylık SYİ değerleri için kuraklık oluşum yüzdeleri Atabey, Eğirdir, Isparta (Merkez), Senirkent, Uluborlu ve Yalvaç istasyonlarnnda sirasiyla; \%39.8, \%47.0, \%52.3, \%51.3, $\% 46.4$ ve $\% 42.6$ olarak belirlenmiştir. 12 aylık kuraklık oluşum yüzdeleri incelendiğinde Isparta (Merkez) ve Senirkent istasyonlarında \% 50 'den fazla kuraklık ihtimalinin görüldüğü, diğer istasyonlarda ise \%50'ye yaklaştı̆̆ görülmektedir. $\mathrm{Bu}$ durum çalışmanın yürütüldüğü tüm ilçelerde kuraklık riskinin az ya da çok olduğunu fakat en fazla kuraklık riski altında Isparta (Merkez) ve Senirkent ilçelerinin bulunduğunu ortaya koymaktadır.

Sonuç olarak, küresel iklim değişikliği ile su kaynaklarında meydana gelen azalmalar ve kullanılabilir su kaynaklarının bilinçsiz bir şekilde tüketilmesi kuraklık oluşumunu ciddi bir şekilde etkilemektedir. Dünyanın birçok bölgesinde hissedilen kuraklık olgusu beraberinde açlık, kitlık ve işsizlik gibi sosyo-ekonomik olumsuzluklardan dolayı toplumlar üzerinde kalıcı ve istenmeyen durumları ortaya çıkarmaktadır. İklim değişikliğinin etkileri doğrultusunda, ülkemizin de içinde bulunduğu Akdeniz 
havzası her geçen gün kuraklığa daha da müsait hale gelmektedir. Türkiye genelinde yağışların genel olarak azalma eğiliminde olduğu düşünüldüğünde, Türkiye gibi yağış rejimi bölgeden bölgeye farklılık gösteren ülkelerde bu olgu daha da büyük bir önem taşımaktadır.

Bu bağlamda kuraklığın tespitinde kullanılan SYİ ve De Martonne-Gottman yöntemleri kiyaslandığında De Martonne-Gottman yönteminin daha ayrıntılı olduğu görülmektedir. De Martonne-Gottman yönteminde kullanılan parametrelerin fazla olmasının yöntemin hassasiyetini arttırdığ 1 söylenebilir. De Martonne-Gottman yönteminde yağış verileri ile sıcaklık verileri birlikte kullanılmaktadır. Diğer taraftan SYİ sadece yağış verisi baz alınarak hesaplanan bir yöntemdir. Böylelikle sicaklık verilerinin etkisi ile De Martonne-Gottman indisinin kuraklığı daha etkili gösterdiği düşünülebilir. Bununla birlikte araştırmada De Martonne-Gottman yöntemi ile SYİ yönteminin tamamen aynı olmasa da benzer sonuçlar verdiği görülmüştür.

Isparta ili, iklim sınıflandırmasında yarı-kurak ve yarınemli bir bölge içerisinde yer almaktadır. $\mathrm{Bu}$ nedenle, kuraklığın izlenmesi ve önceden gerekli önlemlerin alınması büyük önem arz etmektedir. Geçmiş dönemlere ait yağış verilerinin analizi ile kuraklık alanı, süresi ve şiddeti elde edilebilmektedir. Böylece geçmiş yıllarda meydana gelen kuraklık olgusunu ortaya koymak bir bölgede gelecek dönem için kuraklığın tahmininde büyük önem taşımaktadır. Kuraklık, izlenebildiği takdirde etkilerini en aza indirmek, alansal ve zamansal değişimini takip etmek mümkün olabilmektedir.

\section{Kaynaklar}

Acar, E., 2018. Küreselleșme-Neoliberalizm ve Su Yönetimi. Ekin Basım Yayin, Ankara.

Akbaş, A., 2014. Türkiye üzerindeki önemli kurak yıllar. Coğrafi Bilimler Dergisi, 12(2): 101-118.

Akın, M., Akın, G., 2007. Suyun önemi, Türkiye'de su potansiyeli, su havzaları ve su kirliliği. Ankara Üniversitesi Dil ve TarihCoğrafya Fakültesi Dergisi, 47(2): 105-118.

Aktaş, S., Kalyoncuoğlu, Ü.Y., Anadolu Kılıç, N.C., 2018. Eğirdir Göl Havzasının De Martonne Yöntemi ile Kuraklık Analizi. Mühendislik Bilimleri ve Tasarım Dergisi, 6(2): 229-238.

Babalık, A.A., 2014. The Effect of Aspect Factor in IspartaArapdağ 1 Rangeland on the Dry Forage Yield and Botanical Composition. Research Journal of Biotechnology, 9(9): 73-78.

Bhangale, U., More, S., Shaikh, T., Patil, S., More, N., 2020. Analysis of Surface Water Resources Using Sentinel-2 Imagery. Procedia Computer Science, 171: 2645-2654.

De Martonne, E., 1926. Une nouvelle fanction climatologique: l'indice d'aridité. La Météorologie, 2: 449-458.

De Martonne, E., 1942. Nouvelle Carte Modiale de I'indice d'aridit é. Annaes de Géographie, 51: 242-250.

DMI, 2021. Isparta İli İklim Verileri. Tarım ve Orman Bakanlığı, Devlet Meteoroloji İşleri Genel Müdürlüğü, Ankara.

IÇŞìM, 2019. Isparta İli 2018 Yılı Çevre Durum Raporu. Isparta Çevre ve Şehircilik İl Müdürlüğü, 85 s., Isparta.

Karabulut, M., 2020. Standart yağış indeksi kullanılarak Sivas İlinde kuraklık analizi. Uluslararası Sosyal Araştırmalar Dergisi, 13 (71): 216-230.

Karataş, M., Çevik, S., 2010. Stratejik Doğal Kaynak Olarak Su ve Türkiye'nin Konumunun Değerlendirilmesi. Akademik Araştırmalar Dergisi, (45): 1-29.

Kurnaz, L., 2014. Kuraklık ve Türkiye. İstanbul Politikalar Merkezi, İstanbul.
Kurtoğlu, R., 2018. Biyo-Politik Savaşlar: İklim-Su-Gıda-GDOSağlık İstihbaratı. Destek Yayınları, İstanbul.

McKee, T.B., Doesken, N.J., Kleist, J., 1993. The relationship of drought frequency and duration to time scales. 8th Conference on Applied Climatology, January 17-22, California, USA, pp: 179-184.

McKee, T.B., Doesken, N.J., Kleist, J., 1995. Drought monitoring with multiple time scales. 9th Conference on Applied Climatology, January 15-20, Dallas, USA, pp:.233-236.

Mishra, A.K., Singh, V.P., 2010. A review of drought concepts. Journal of hydrology, 391(1-2), 202-216.

MGM, 2016. De Martonne Kuraklık İndeksine Göre Türkiye İklimi, T.C. Orman ve Su İşleri Bakanlığı Meteoroloji Genel Müdürlüğü, Araştırma Dairesi Başkanlığı Klimatoloji Şube Müdürlüğü,

Ankara, https://www.mgm.gov.tr/FILES/iklim/iklim_siniflandirmalari/ Demartonne.pdf, Erişim: 15.03.2021.

Özfidaner, M., Topaloğlu, F., 2020. Standart Yağış İndeksi Yöntemi ile Güneydoğu Anadolu Bölgesinde Kuraklık Analizi. Toprak Su Dergisi, 9(2):130-136.

Panofsky, H.A., Brier, G.W., 1958. Some applications of statistics to meteorology. Pennsylvania State University Press, USA.

Pathak, A.A., Dodamani, B.M., 2016. Comparison of two hydrological drought indices. Perspectives in science, 8: 626628.

Şahin, Ü., Kurnaz, L., 2014. İklim değişikliği ve kuraklık. Sabanc1 Üniversitesi, İstanbul Politikalar Merkezi, Stiftung Mercator Girişimi, İstanbul, https://ipc.sabanciuniv.edu/Content/Images/CKeditorImages/20 200326-02030608.pdf. Erişim: 15.03.2021.

Thom, H.C.S., 1966. Some Methods of Climatological Analysis. World Meteorological Organization, World Meteorological Organization Technical Note, No: 81.

Topçu, E., Karaçor, F., 2021. Erzurum İstasyonunun Standartlaştırılmış Yağış Evapotranspirasyon İndeksi ve Bütünleşik Kuraklık İndeksi Kullanılarak Kuraklık Analizi. Politeknik Dergisi, 24(2): 565-574.

Turan, E., Bayrakdar, E., 2020. Türkiye'nin Su Yönetim Politikaları: Ulusal Güvenlik Açısından Bir Değerlendirme. Uluslararası Politik Araştırmalar Dergisi, 6(2): 1-19.

Uçar, Y., Topçu, E., Demirel, E., 2019. Standartlaştırılmış Yağış İndeksi Yöntemi ile Isparta İli Kuraklık Analizi. Türk Bilim ve Mühendislik Dergisi, 1(1): 5-16.

Valipour, M., 2015. Land use policy and agricultural water management of the previous half of century in Africa. Applied Water Science, 5(4): 367-395.

Wilhite, D.A., Glantz, M.H., 1985. Understanding: the drought phenomenon: the role of definitions. Water international, 10(3): 111-120.

Wu, H., Hayes, M.J., Weiss, A., 2001. An evaluation of the standardized precipitation index, the Chine z-index and the statistical z-score. International Journal of Climatology, 21: 745758.

Yokomatsu, M., Ishiwata, H., Sawada, Y., Suzuki, Y., Koike, T., Naseer, A., Cheema, M.J.M., 2020. A multi-sector multi-region economic growth model of drought and the value of water: a case study in Pakistan. International Journal of Disaster Risk Reduction, 43: 101368.

Zarei, A.R., Eslamian, S., 2017. Trend assessment of precipitation and drought index (SPI) using parametric and non-parametric trend analysis methods (Case study: Arid regions of southern Iran). International Journal of Hydrology Science and Technology,7(1): 12-38.

Zhang, Y., Li, W., Chen, Q., Pu, X., Xiang, L., 2017. Multi-models for SPI drought forecasting in the north of Haihe River Basin, China. Stochastic Environmental Research and Risk Assessment, 31(10): 2471-2481. 